\title{
2005-06 Farm Bill Survey: Florida Producer Views on Conservation and Environmental, Trade, and Food System and Regulatory Policies ${ }^{1}$
}

Rodney L. Clouser ${ }^{2}$

\section{Introduction}

This is the third fact sheet in a series of four which describes attitudes and opinions of Florida farm producers toward legislation that may be considered as the U.S. Congress debates the next farm bill. Florida was one of 27 states that participated in a national farm producer survey. The survey was completed in the winter of 2005-06, and the data reported are based on 244 valid and usable surveys that were returned.

Florida farm producers have participated in these surveys just prior to enactment of each new farm bill legislation since 1985 . Of the 27 states participating in the survey, five were from the South: Alabama, Florida, Georgia, North Carolina, and Texas. Nationally, southern states accounted for about 30 percent of all farms included in the statistical analysis. In total, the southern and north central regions accounted for 76 percent of farms used for statistical analysis. 
just below a majority threshold (49 percent). No federal assistance of any sort for any of the environmental goals ever exceeded 17 percent (open space protection), and only more than 25 percent of those responding indicated they didn't know/had no opinion on the environmental goals of maintenance of biodiversity ( 26 percent) and carbon sequestration (36 percent).

Producers responding to the survey were asked about tailoring conservation programs by block grants to individual states. Specifically, they were asked whether federal funds should be transferred by block grants with more authority given to individual states to implement conservation programs. By a ratio of more than two-to-one (50 percent agreed or strongly agreed and 24 percent disagreed or strongly disagreed), Florida producers indicated support for this policy option.

Florida producers have some land enrolled in the Conservation Reserve Program (CRP) and, like with other states, most of the contracts for CRP land expire by 2010. About 30 percent of the producers support keeping current CRP rules, letting contracts expire on-schedule and then letting those lands compete for re-enrollment when the contracts expire. Almost 24 percent support elimination of the current CRP program when contracts expire. Just over 23 percent prefer the policy alternative of allowing lands with the highest environmental benefits to be automatically eligible for re-enrollment in the CRP program but at existing annual rental rates. Finally, 10 percent support a reduction of land in the CRP by restricting future enrollments to high-priority, environmentally-sensitive lands only.

\section{The Conservation Security Program (CSP)} provides cost-share assistance, incentive payments, and technical assistance to producers adopting or maintaining targeted conservation programs on working lands. Forty percent of Florida producers support continuation of the CSP, as federal funding allows, on a watershed-by-watershed basis. Almost 25 percent of the respondents support elimination of the program as existing contracts expire. Finally, 20 percent of Florida producers support the policy option of increasing federal funding to immediately allow for nationwide implementation of the program.

\section{Trade Policy}

Responses by Florida producers demonstrated one overwhelming opinion. Three-quarters ( 75 percent) agreed or strongly agreed that labor laws, environmental impacts, and food safety standards should be included as part of international trade negotiations and agreements (Table 2). Producers have been suggesting for many years that the "playing field is not level" when it comes to trade agreements and the standards of production in many foreign countries lag U.S. standards. The response by Florida producers to this question confirms that those topics still remain an issue when it comes to trade agreements.

Florida producers also indicated a lukewarm response to the continuation of trade agreements such as WTO (World Trade Organization). About 36 percent indicated that they disagreed or strongly disagreed with the need to continue to pursue international trade agreements. About 34 percent were on the opposite end of the scale and indicated that they agreed or strongly agreed that the United States should continue to pursue trade agreements.

Over 42 percent of those responding indicated that they strongly agreed or agreed that the United States should emphasize domestic and social policy goals rather that trade policies. This might include income, production, and environmental programs rather than trade-related programs. About half that number (22 percent) disagreed or strongly disagreed that the emphasis should be on domestic and social policy rather than trade policy.

By a ratio of almost two-to-one (34 percent agreed or strongly agreed and 18 percent disagreed or strongly disagreed), Florida producers felt if the United States were to withdraw from the WTO that it would cause increased problems for U.S. producers. Two concerns might be (1) greater access problems to international markets and (2) more problems in exporting U.S. goods into other countries. On a closely related topic, just over 30 percent of respondents indicated that they either disagreed or strongly disagreed that the United States should withdraw from the WTO. Almost 25 percent either indicated that they agreed or strongly agreed that the 
United States should withdraw from the WTO and another 25 percent indicated that they didn't know whether the United States should withdraw.

Florida producers were also relatively dispersed on their response to whether food trade should be used as a policy tool in sanctions against other countries. This would most often happen due to political, social, or terrorist threats, with prohibition of trade with these countries being common. About 32 percent agreed or strongly agreed that prohibiting food trade as part of sanctions should be eliminated, 28 percent indicated that food trade should continue to be used as a policy tool, and 13 percent were neutral on the use of this trade policy tool.

\section{Food System and Regulatory Policy}

Florida producers were asked a series of food system and regulatory policy questions (Table 3). A majority of producers agreed or strongly agreed on a number of these questions. Over 84 percent supported mandatory rules identifying the country-of-origin labeling (COOL) for food products, and over 71 percent thought the government should increase efforts to improve the traceability of food between producers and consumers. The adoption of mandatory animal identification rules to improve animal health and food safety monitoring was supported by 62 percent of producers. Just fewer than 57 percent supported the policy option of labeling food products made with biotechnology regardless of scientifically-determined differences in the products.

Florida producers agreed or strongly agreed that the government should establish guidelines for voluntary BSE testing of cattle by private industry (45 percent), the government should adopt mandatory BSE testing for all cattle over 30 months of age (44 percent), and voluntary labeling guidelines should be established (44 percent) on what country-of-origin labeling (COOL) means for food products. The only policy alternative where over 21 percent of producers disagreed or strongly disagreed was what voluntary COOL guidelines means for food products (38 percent).

\section{Summary}

Florida producers were supportive of both financial and technical assistance for environmental goals related to water quality protection (63 percent), wildlife habitat protection (54 percent), and soil erosion control (51 percent). Three-quarters (75 percent) agreed or strongly agreed that labor laws, environmental impacts, and food safety standards should be included in international trade negotiations and agreements. By a ratio of more than two-to-one (50 percent agreed or strongly agreed and 24 percent disagreed or strongly disagreed), Florida producers would support federal fund transfers by block grants to states, with more authority given to individual states to implement conservation programs. The majority of Florida producers in the survey support mandatory rules for COOL ( 84 percent), improved traceability of food between producers and consumers (71 percent), adoption of mandatory animal identification rules (62 percent), and labeling food products made with biotechnology regardless of whether there is a scientifically-determined difference in the product (57 percent).

\section{References}

Clouser, Rodney L. 2006. 2005-06 Farm Bill Survey: Characteristics of Florida Producers Who Participated. Electronic Data Information Source (EDIS) FE663. Food and Resource Economics Department, University of Florida, Gainesville, FL. http://edis.ifas.ufl.edu/FE663.

Clouser, Rodney L. 2006. 2005-06 Farm Bill Survey: Florida Producer Views on Rural Development; Open Space and Farmland Preservation; Labor; Research Funding Allocation; and Inclusion of Fruits, Vegetables, and Specialty Crops in Federal Government Commodity Programs. Electronic Data Information Source (EDIS) FE664. Food and Resource Economics Department, University of Florida, Gainesville, FL. http://edis.ifas.ufl.edu/FE664. 
Table 1. Levels of support for various environmental goals.

\begin{tabular}{|lcccc|}
\hline \hline Program & $\begin{array}{c}\text { No Federal } \\
\text { Assistance }\end{array}$ & $\begin{array}{c}\text { Technical } \\
\text { Assistance Only }\end{array}$ & $\begin{array}{c}\text { Technical \& } \\
\text { Financial } \\
\text { Assistance }\end{array}$ & $\begin{array}{c}\text { No Opinion or } \\
\text { Don't Know }\end{array}$ \\
\hline Water Quality Protection & $8 \%$ & $20 \%$ & $63 \%$ & $6 \%$ \\
Soil Erosion Control & $7 \%$ & $30 \%$ & $51 \%$ & $7 \%$ \\
Air Quality Protection & $9 \%$ & $27 \%$ & $49 \%$ & $10 \%$ \\
Wildlife Habitat Protection & $11 \%$ & $23 \%$ & $54 \%$ & $8 \%$ \\
Open Space Protection & $17 \%$ & $23 \%$ & $38 \%$ & $16 \%$ \\
Management of Animal Waste & $12 \%$ & $32 \%$ & $35 \%$ & $16 \%$ \\
Carbon Sequestration & $9 \%$ & $22 \%$ & $27 \%$ & $36 \%$ \\
Maintenance of Biodiversity & $10 \%$ & $24 \%$ & $34 \%$ & $26 \%$ \\
\hline Note: Percentages in tables will not add to 100\% because those who did not answer were not reported. & \\
\hline \hline
\end{tabular}

Table 2. Florida producer views on trade policies.

\begin{tabular}{|c|c|c|c|c|}
\hline Policy Alternative & $\begin{array}{l}\text { Disagree or } \\
\text { Strongly } \\
\text { Disagree }\end{array}$ & Neutral & $\begin{array}{l}\text { Agree or } \\
\text { Strongly } \\
\text { Agree }\end{array}$ & Don't Know \\
\hline $\begin{array}{l}\text { The United States should continue to pursue free-trade } \\
\text { agreements (e.g., WTO) to reduce and eliminate trade } \\
\text { barriers }\end{array}$ & 36 & 18 & 34 & 7 \\
\hline $\begin{array}{l}\text { Labor laws, environmental impacts, and food safety } \\
\text { standards should be included in international trade } \\
\text { negotiations }\end{array}$ & 9 & 6 & 75 & 5 \\
\hline $\begin{array}{l}\text { To comply with the recent WTO ruling on cotton, the } \\
\text { United States should eliminate export credits and } \\
\text { industry payments, such as Step- } 2 \text { cotton payments }\end{array}$ & 8 & 14 & 23 & 48 \\
\hline $\begin{array}{l}\text { The United States should emphasize domestic } \\
\text { economic and social policy goals rather than trade } \\
\text { policies }\end{array}$ & 22 & 13 & 42 & 18 \\
\hline The United States should withdraw from the WTO & 30 & 19 & 24 & 20 \\
\hline $\begin{array}{l}\text { If the United States withdraws from the WTO, U.S. } \\
\text { producers will face greater market access problems } \\
\text { getting agricultural exports into other countries }\end{array}$ & 18 & 17 & 34 & 25 \\
\hline $\begin{array}{l}\text { The United States should eliminate unilateral sanctions } \\
\text { prohibiting food trade with certain other countries }\end{array}$ & 28 & 13 & 32 & 22 \\
\hline
\end{tabular}


Table 3. Florida producer views on food system and regulatory policies.

\begin{tabular}{|c|c|c|c|c|}
\hline Policy Alternative & $\begin{array}{l}\text { Disagree or } \\
\text { Strongly } \\
\text { Disagree }\end{array}$ & Neutral & $\begin{array}{c}\text { Agree or } \\
\text { Strongly } \\
\text { Agree }\end{array}$ & Don't Know \\
\hline $\begin{array}{l}\text { The government should implement mandatory } \\
\text { labeling rules to identify the country of origin on } \\
\text { food products }\end{array}$ & 7 & 3 & 84 & 1 \\
\hline $\begin{array}{l}\text { The government should implement voluntary } \\
\text { labeling guidelines to better establish what the } \\
\text { identification of the country of origin means for } \\
\text { food products }\end{array}$ & 38 & 7 & 44 & 5 \\
\hline $\begin{array}{l}\text { The government should increase efforts to } \\
\text { improve traceability of food products from the } \\
\text { consumer back to the producer }\end{array}$ & 10 & 11 & 71 & 4 \\
\hline $\begin{array}{l}\text { The government should adopt mandatory animal } \\
\text { identification rules to improve animal health and } \\
\text { food safety monitoring efforts }\end{array}$ & 14 & 14 & 62 & 5 \\
\hline $\begin{array}{l}\text { The government should adopt mandatory BSE } \\
\text { testing of all cattle over } 30 \text { months of age }\end{array}$ & 18 & 15 & 44 & 17 \\
\hline $\begin{array}{l}\text { The government should establish guidelines for } \\
\text { voluntary BSE testing of cattle by private industry }\end{array}$ & 19 & 16 & 45 & 15 \\
\hline $\begin{array}{l}\text { Food products made with biotechnology should be } \\
\text { labeled regardless of whether there is a } \\
\text { scientifically-determined difference in the product }\end{array}$ & 17 & 13 & 57 & 9 \\
\hline
\end{tabular}

